\title{
Predictors of Complications and Mortality in Patients with Self-Expanding Metallic Stents for the Palliation of Malignant Colonic Obstruction
}

\author{
Mafalda Sousa Rolando Pinho Luísa Proença Joana Silva Ana Ponte \\ Jaime Rodrigues João Carvalho \\ Gastroenterology Department, Centro Hospitalar de Vila Nova de Gaia-Espinho, Vila Nova de Gaia, Portugal
}

Keywords

Colorectal neoplasms · Endoscopy · Intestinal obstruction ·

Metals $\cdot$ Palliative care $\cdot$ Stents

\section{Abstract}

Introduction: Self-expanding metallic stents (SEMS) for palliative purposes in malignant colonic obstruction are an alternative to surgery that has gained popularity over time. Methods: We performed a retrospective study of patients submitted to SEMS for palliation of obstructing malignant colorectal cancer from 2005 to 2015 to evaluate predictive clinical factors for complications and mortality. Results: Forty-five patients with high rates of technical and clinical success were included (97.8 and $95.6 \%$, respectively), with complications occurring in $17.8 \%$ (8.9\% perforations, $4.4 \%$ obstructions, and $4.4 \%$ migrations). The length of the stenosis was superior in patients with complications $(p=0.01) ; 11.1 \%$ of patients had a re-intervention (2.2\% surgery and $8.9 \%$ placement of another SEMS). Relief of obstruction without intervention was maintained until death in $77.8 \%$ of patients and in $81.4 \%$ of patients who had immediate clinical success. The mortality rate was $37.2 \%$ at 30 days, $56.5 \%$ at 60 days, and $87.5 \%$ at 1 year. There were no predictors of survival identified, including age, sex, tumor stage, metastasis, or complications of the procedure. Discussion and Conclusions: In this study, SEMS placement was associated with a high rate of technical and clinical success and a low rate of complications, being an option to palliate patients with obstructive neoplasia. The length of the stenosis was associated with a greater risk of complications. The majority of stentrelated complications can be managed successfully without surgery.

(c) 2016 Sociedade Portuguesa de Gastrenterologia Published by S. Karger AG, Basel

Dr. Mafalda Sousa Gastroenterology Department Centro Hospitalar de Vila Nova de Gaia-Espinho Rua Conceição Fernandes, s/n, PT-4434-502 Vila Nova de Gaia (Portugal) E-Mail mafalda_m_p_sousa@ hotmail.com 


\section{Preditores de Complicações e Mortalidade nas Próteses Metálicas Auto-Extensíveis para Paliação da Oclusão Colo-Rectal Maligna}

\author{
Palavras Chave \\ Neoplasias colorretais · Endoscopia · Oclusão intestinal · \\ Metais · Cuidados paliativos · Próteses
}

\section{Resumo}

Introdução: As próteses metálicas auto-extensíveis (PMAE), como tratamento paliativo na oclusão colo-retal maligna, são uma alternativa à cirurgia que tem ganho popularidade nos últimos tempos. Métodos: Estudo retrospetivo de pacientes submetidos a PMAE para paliação de cancro colo-retal maligno oclusivo de 2005 a 2015, com o objetivo de avaliar fatores clínicos preditivos de complicações e mortalidade. Resultados: Foram incluídos 45 pacientes, tendo-se verificado taxas de sucesso técnico e clínico elevadas (97.8 e 95.6\%, respetivamente), com complicações a ocorrem em $17.8 \%$ dos pacientes $(8.9 \%$ perfurações, $4.4 \%$ obstruções e $4.4 \%$ migrações). O comprimento da estenose foi superior em pacientes com complicações $(p=0.01)$. 11.1\% dos pacientes foram submetidos a uma re-intervenção $(2.2 \%$ cirurgia e $8.9 \%$ colocação de outra PMAE). A resolução da obstrução sem intervenção adicional foi mantida até à morte em $77.8 \%$ dos pacientes e em $81.4 \%$ daqueles que tiveram sucesso clínico. A taxa de mortalidade foi de $37.2 \%$ aos 30 dias, $56.5 \%$ aos 60 dias e $87.5 \%$ ao ano. Não houve preditores de sobrevida identificados, incluindo idade, sexo, estadiamento do tumor, metástases ou complicações do procedimento. Discussão e Conclusões: Neste estudo, a colocação PMAE foi associada a taxas de sucesso técnico e clínico elevadas, com baixo número de complicações, sendo uma opção viável para o tratamento paliativo de doentes com neoplasias obstrutivas. $O$ comprimento da estenose foi associado a um maior risco de complicações. A maioria das complicações relacionadas com a prótese foi resolvida com sucesso sem necessidade de cirurgia. @ 2016 Sociedade Portuguesa de Gastrenterologia Publicado por S. Karger AG, Basel

\section{Introduction}

Colorectal cancer is one of the most common cancers in Western societies, and obstruction is the presenting symptom in $10-30 \%$ of patients $[1,2]$; $70 \%$ of these patients already have advanced disease, and only $50 \%$ are candidates for curative surgery at presentation $[3,4]$.

The traditional treatment for unresectable tumors was diverting colostomy with permanent stoma creation for relieving symptoms of obstruction. Unfortunately, this procedure is associated with substantial drawbacks, including high mortality and morbidity, as well as a detrimental impact on quality of life when irreversible ostomies necessitate a colostomy bag [5-7].

In the past 2 decades, the use of self-expanding metallic stents (SEMS) has drawn interest since it was first reported in 1991 by Dohmoto for palliation of malignant colonic obstruction [8].

Two randomized trials with 30 and 48 patients comparing surgery to palliative stenting showed similar effectiveness and survival but better quality of life, less periinterventional morbidity and mortality, and cost-effectiveness in SEMS-treated patients $[9,10]$.

In contrast, a randomized trial with 21 patients had a high number of serious adverse events in the nonsurgical group (6 perforations in 11 patients), which led to its early closure. This unexpected high rate of perforation may be specifically WallFlex-related or enteral stent-related in patients on chemotherapy [11].

A meta-analysis by Zhao et al. [12] in 2013 showed a significantly higher rate of clinical relief of obstructions in patients submitted to surgery, but in SEMS-treated patients the hospital stay, ICU admission rate, and overall complication rate was lower. The overall survival time was similar. Another meta-analysis by Liang et al. [13] in 2014 revealed that the SEMS group had less successful relief of obstruction, but also lower overall complication and mortality rates.

According to the guidelines of the European Society of Gastrointestinal Endoscopy [14], SEMS placement is the preferred treatment for palliation in malignant colonic obstruction.

Factors likely to influence the initial success of SEMS include the site of obstruction, the length of the obstruction, stent characteristics, and the insertion technique employed [15].

The aim of this study was to evaluate predictive clinical factors for complications and mortality in patients treated with SEMS for palliation of obstructive colorectal cancer.

GE Port J Gastroenterol 2017;24:122-128 DOI: $10.1159 / 000452697$ 
Table 1. Demographic and clinical characteristics of the patients

$\begin{array}{lc}\text { Age, years } & 78.9(11) \\ \text { Sex } & \\ \quad \text { Male } & 23(51.1 \%) \\ \text { Female } & 22(48.9 \%) \\ \text { ECOG stage } & \\ 0 & 0(0 \%) \\ 1 & 8(17.8 \%) \\ 2 & 5(11.1 \%) \\ 3 & 14(31.1 \%) \\ 4 & 17(37.8 \%) \\ \text { Tumor stage } & 18(40.0 \%) \\ \text { III } & 27(60.0 \%) \\ \text { IV } & 0(0 \%) \\ \text { Previous chemotherapy/radiotherapy } & \\ \text { Stenosis location } & 39(86.7 \%) \\ \quad \text { Rectosigmoid colon } & 2(4.4 \%) \\ \text { Splenic flexure } & 1(2.2 \%) \\ \text { Transverse colon } & 3(6.7 \%) \\ \quad \text { Hepatic flexure } & 58.3(23.6) \\ \text { Stenosis length, cm } & 5.5[3-10] \\ \text { Duration of hospitalization, days } & \\ \text { Follow-up until death or complication, } & \\ \quad \text { days } & 36.5[12.25-137.5] \\ \text { Patients with complications during } & \\ \text { follow-up } & 8(19 \%) \\ \text { Deaths during follow-up } & 38(84.4 \%) \\ \text { Patients without complications and alive } & \\ \quad \text { at the end of follow-up } & 6(13.3 \%) \\ \end{array}$

Values are presented as $\mathrm{n}(\%)$, mean (SD), or median [interquartile range].

ECOG, Eastern Cooperative Oncology Group.

\section{Patients and Methods}

\section{Patient Selection}

Patients submitted to SEMS for palliation of obstructive colorectal cancer from January 2005 to December 2015 were included. Colonic obstruction was diagnosed based on anamnesis (inability to pass stools and air), physical examination, and radiologic features. The assignment of patients to undergo palliative treatment was based on unacceptable surgical risk in view of advanced age or comorbidities, or on the presence of locally advanced disease or distant metastases. Exclusion criteria were low rectal tumors, incomplete data, loss to follow-up, and patients with malignant strictures without obstructive symptoms.

Clinical charts were retrospectively reviewed for patient demographics, Eastern Cooperative Oncology Group (ECOG) stage, location of primary and metastatic disease, length of the tumor (measured by CT scan), cancer stage, palliative chemotherapy, technical success, clinical success, stent diameter and length, complications, duration of hospital stay, re-interventions, morbidity, mortality, and survival.

\section{Technique and Stents}

All SEMS were placed under endoscopic and fluoroscopic guidance, by gastroenterologists with experience in more than $20 \mathrm{co}-$ lonic stent placements. Hanarostent ${ }^{\circledR}$ stents (M.I. Tech., Seoul, Korea) $22-24 \mathrm{~mm}$ in diameter and $80-140 \mathrm{~mm}$ in length were used. Correct positioning was confirmed using both fluoroscopy and endoscopy. Balloon pre-dilation was not performed in any case.

\section{Outcomes}

The primary endpoints included survival as well as complication-free survival and its predictors. Complications were defined as events that led to re-intervention, required patient admission to the hospital, or caused death, and included perforation, migration, and obstruction. They were further classified as early if they occurred within 30 days of palliative stenting and late if they occurred after 30 days.

The secondary endpoints included technical success, clinical success, and stent patency. Technical success was defined as successful deployment of the stent across the stricture, and clinical success was defined as relief of obstructive symptoms within $24 \mathrm{~h}$ after stent placement. Stent patency was defined as the period between stent placement and recurrence of obstructive symptoms due to obstruction or migration.

\section{Follow-Up}

Follow-up data were obtained by reviewing patients' charts for complications, re-interventions, hospital admissions, and death. Patients were followed until death or if alive until the date of data collection (February 2016).

\section{Statistical Analysis}

Statistical analysis was performed using the Statistical Package for Social Sciences (SPSS) program version 20 (IBM Corp., Armonk, NY, USA).

Categorical variables are presented as frequencies and percentages and continuous variables as means and standard deviations or medians and interquartile ranges in the case of skewed distributions. $\chi^{2}$ test or Fisher test and Student $t$ test were used to compare noncontinuous and continuous data, respectively.

Survival, progression-free survival, complication-free survival, and stent patency over time were calculated using the Kaplan-Meier method. Data were censored at the time of endpoint achievement or at the end of follow-up. Categorical predictors of survival were compared using the log-rank test and continuous predictors of survival were evaluated using the Cox proportional hazard model.

Age, sex, ECOG stage, location and stage of the tumor, presence of metastasis, previous chemotherapy, and stenosis length were the variables included in the analysis. A $p$ value $<0.05$ was considered statistically significant.

\section{Results}

\section{Patients and Demographics}

From January 2005 to December 2015, 45 patients were eligible for this study. Their demographic and clinical characteristics are summarized in Table 1. 


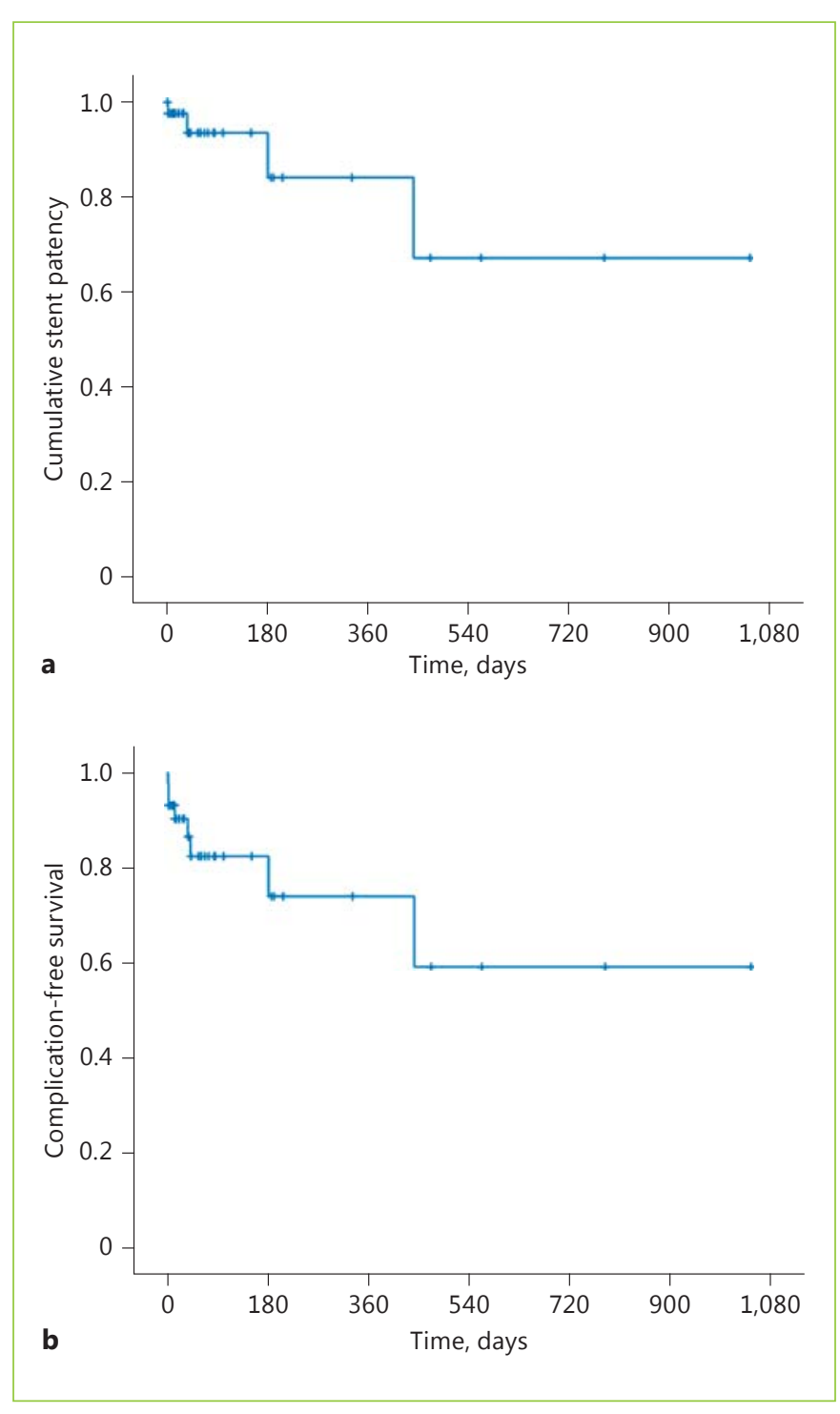

Fig. 1. a Kaplan-Meier curve showing cumulative stent patency over time. b Kaplan-Meier curve showing complication-free survival.

\section{Technical and Clinical Success}

SEMS insertion was technically successful in $97.8 \%$ $(n=44)$ and clinically successful in $95.6 \%(n=43)$. The reason for the only case of technical failure was the inability to pass the guidewire across the strictured segment. The patient underwent successful emergent surgery with colostomy. One patient did not experience resolution of symptoms within $72 \mathrm{~h}$ after intervention, but no re-intervention was performed since he died from pulmonary embolism.

SEMS and Malignant Colonic Obstruction
Table 2. Early and late complications

\begin{tabular}{|c|c|c|c|c|}
\hline & $\begin{array}{l}\text { Early } \\
\text { compli- } \\
\text { cations }\end{array}$ & $\begin{array}{l}\text { Late } \\
\text { compli- } \\
\text { cations }\end{array}$ & Overall & Management \\
\hline Perforation & 3 & 1 & $4(8.9 \%)$ & $\begin{array}{l}\text { death (3), } \\
\text { surgery (1) }\end{array}$ \\
\hline Obstruction & 1 & 1 & $2(4.4 \%)$ & new SEMS (2) \\
\hline Migration & 0 & 2 & $2(4.4 \%)$ & new SEMS (2) \\
\hline
\end{tabular}

SEMS, self-expanding metallic stent.

Table 3. Predictors of complications and mortality ( $p$ values)

\begin{tabular}{llll}
\hline Predictors & $\begin{array}{l}\text { Complica- } \\
\text { tions }\end{array}$ & $\begin{array}{l}\text { Complication- } \\
\text { free survival }\end{array}$ & $\begin{array}{l}\text { Sur- } \\
\text { vival }\end{array}$ \\
\hline Age & 0.294 & 0.374 & 0.343 \\
Sex (female/male) & 0.698 & 0.918 & 0.164 \\
Location (right/left) & 1.000 & 0.177 & 0.404 \\
Stage (III/IV) & 0.690 & 0.803 & 0.261 \\
Metastasis (yes/no) & 0.240 & 0.391 & 0.296 \\
Length of stenosis & $0.012^{*}$ & $0.014^{*}$ & 0.807 \\
ECOG stage & 0.676 & 0.311 & 0.235 \\
Complication (yes/no) & - & - & 0.984 \\
\hline
\end{tabular}

* Statistically significant $(p<0.05)$.

\section{Long-Term Success}

Relief of obstruction without intervention was maintained from stent insertion until death in 35 of 45 patients (77.8\%) and in 35 of 43 patients who had immediate clinical success $(81.4 \%)$. Relief of obstruction without surgery, but requiring a second stent, was maintained until death in 39 of 45 patients (86.7\%) and in 39 of 43 patients (90.7\%), respectively.

Loss of stent patency occurred in 4 of 45 patients $(8.9 \%)$ as a result of stent dysfunction (2 stent obstructions and 2 migrations). At 180 days, stent patency was present in $84.2 \%$ of the patients. Stent patency over time is depicted in Figure 1a.

\section{Complications and Survival}

In the early post-procedure period, 3 patients developed symptoms and radiologic evidence suggestive of perforation that led to death (mean interval of 5 days after SEMS placement). One patient presented with obstructive symptoms 2 days after SEMS placement caused by

GE Port J Gastroenterol 2017;24:122-128 DOI: $10.1159 / 000452697$ 


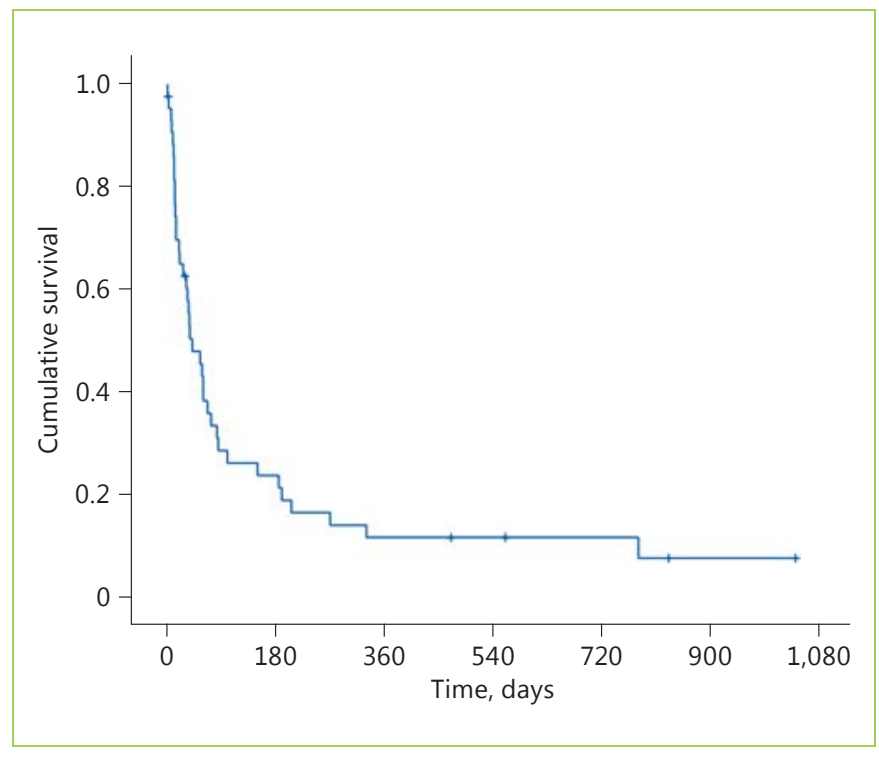

Fig. 2. Kaplan-Meier curve showing overall cumulative survival.

kinking of the stent, which was resolved endoscopically by placement of a new stent.

Four patients had late complications, including 1 perforation (41 days after requiring surgical management), 1 obstruction (36 days after requiring surgical management), and 2 migrations (180 and 440 days after requiring surgical management), requiring new endoscopic procedures with stent placement in all 3 cases (Table 2). Complication-free survival was $74.2 \%$ at 180 days (Fig. 1b). Overall, only 5 patients had a re-intervention (11.1\%), including 4 endoscopic (8.9\%) and 1 surgical intervention (2.2\%).

Gender, ECOG stage, location of the tumor, and presence of metastasis were not statistically significant predictors of complication-free survival ( $p \geq 0.05$ ). The length of the stenosis was superior in patients with a lower complication-free survival (74.3 vs. $53.7 \mathrm{~mm}, p=0.01)$. Likewise, only the length of the stenosis was associated with the presence of complications $(p=0.01)$, as seen in Table 3 .

The median length of hospital stay after SEMS insertion was 5 days. The 30 -day mortality rate was $37.2 \%$, the 60 -day mortality rate $61.3 \%$, and the 1 -year mortality rate $87.9 \%$ (Fig. 2).

There were no predictors of survival, including age, sex, stage of the tumor, length of the stenosis, presence of metastasis (Fig. 3a), or complications of the procedure (Fig. 3b). The $p$ values for predictors of complications and mortality are summarized in Table 3.

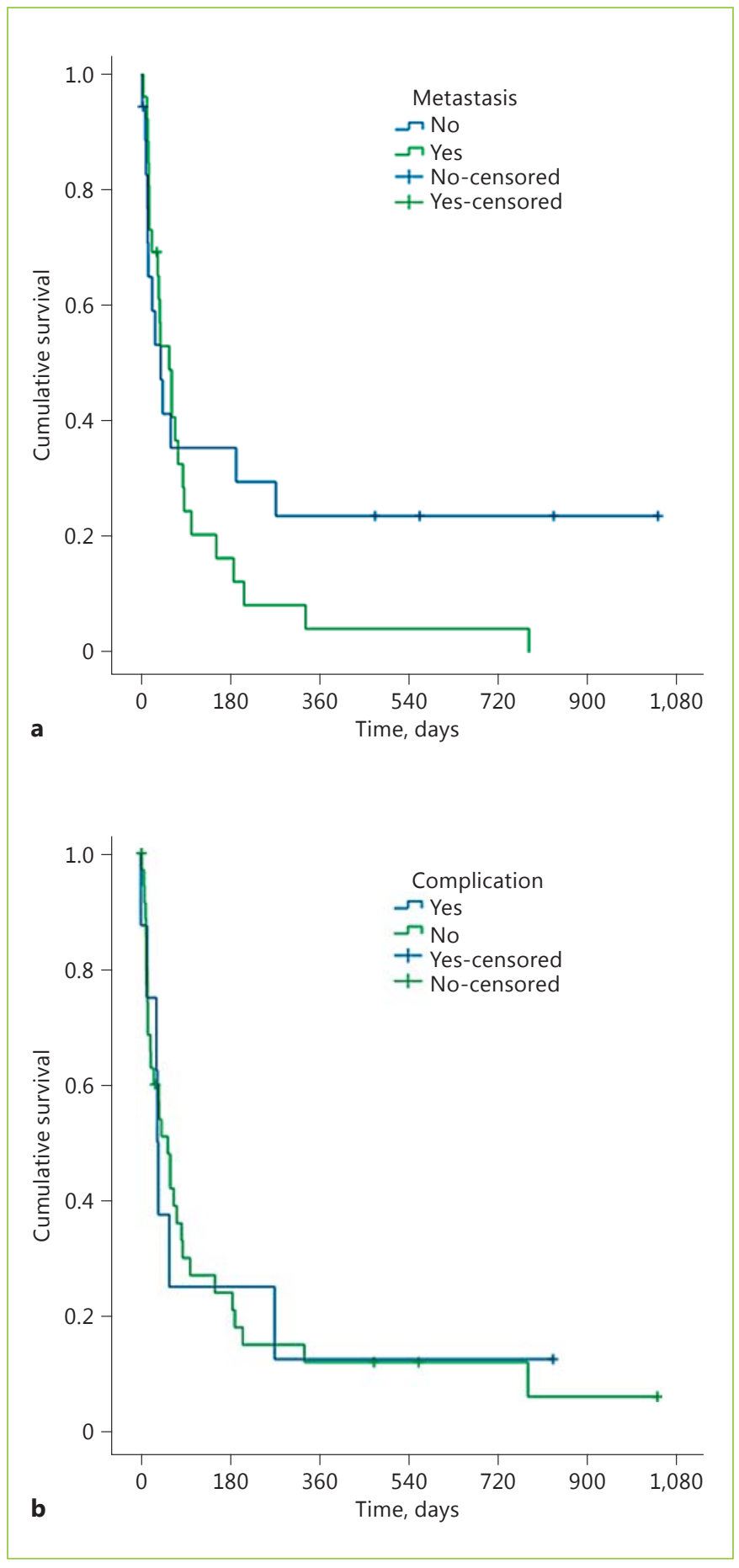

Fig. 3. a Kaplan-Meier curve analyzing the impact of metastases on survival. b Kaplan-Meier survival curve analyzing the impact of complications on survival.
Sousa/Pinho/Proença/Silva/Ponte/ Rodrigues/Carvalho 


\section{Discussion and Conclusions}

Colonic obstruction is a condition with high morbidity and mortality because of the generally poor condition of these patients [16].

Prospective studies, retrospective studies, and previously addressed randomized trials that compare palliation approaches (SEMS versus decompressive colostomy/ileostomy) present contradictory findings and a significant heterogeneity regarding tumor location, staging, study design, follow-up, and overall morbidity [9-11].

Some suggest that palliative SEMS does not have a significant advantage over palliative surgery for decompressing unresectable malignant colorectal occlusion because some patients may have higher survival than expected and consequently more complications and more need for re-interventions. This is mainly due to late complications, suggesting that patients with incurable obstructing colorectal cancer should be offered other treatments different from SEMS, especially if eligible for chemotherapy $[17,18]$. On the other hand, others demonstrate shorter hospital stay, comparable risk of short-term complications and mortality, and cost-effectiveness $[8,12]$. Sustained relief of obstructive symptoms without re-intervention is an important outcome, and several studies show that long-term clinical efficacy of SEMS can be maintained until death in the great majority of patients [19-21].

In this study a high technical and clinical success rate for SEMS insertion was demonstrated, since only 1 patient did not achieve decompression despite successful stent deployment. Although the majority of SEMS procedures were performed in the rectosigmoid colon, right colonic obstruction was also managed endoscopically without increased complications.

The perforation rate was of $8.9 \%$, comparable to previous studies where the perforation rate ranged between 0 and $12.8 \%[14,15]$. Accumulating data suggest a significantly increased risk of perforation in patients receiving bevacizumab, although in this study no patients were submitted to this drug [22]. The stent migration rate was $4.4 \%$, also comparable to previously described rates (0$4.9 \%)[6,14]$.

Despite the potential for complications, this series confirms that the majority of patients can be managed successfully without surgery, since relief of obstruction without surgery was maintained from stent insertion until death in $86.7 \%$ of patients.

The length of the stenosis was the only independent predictor associated with lower complication-free surviv- al. This may be an important factor when considering SEMS placement or surgery.

The high mortality rates in this study were probably a consequence of poor patient condition, including advanced age (median age 78.9 years), advanced colorectal cancer (mainly stage IV), and multiple comorbidities (mainly ECOG stage 4), since complications of SEMS insertion were not a significant predictor of mortality.

With the increasingly aggressive surgical management of metastases with curative intent, the characteristics of the patients selected for stenting in this cohort may have changed over the study interval and will continue to evolve [23].

The weaknesses of this study include its retrospective nature, the small number of patients from a single institution, and lack of control group, although a control group in this subset of patients would not be ethically feasible [14].

In conclusion, SEMS placement is a viable intervention for malignant large bowel obstruction. With careful patient selection and appropriately experienced endoscopists, technical and clinical success rates should be high and perforation rates should be low.

\section{Statement of Ethics}

This study did not require informed consent nor review/approval by the appropriate ethics committee.

\section{Disclosure Statement}

The authors have no conflicts of interest to declare.

References

1 Deans GT, Krukowski ZH, Irwin ST: Malignant obstruction of the left colon. Br J Surg 1994;81:1270-1276.

2 Philips R, Hitsinfer R, Fry JS, Fielding LP: Malignant large bowel obstruction. Br J Surg 1985;72:296-302.

3 Alvarez JA, Baldonedo RF, Bear IG, Truain N, Pire G, Alvarez P: Presentation, treatment and multivariate analysis of risk factors for obstructive and perforative colorectal carcinoma. Am J Surg 2005; 190:376-382.

4 Dionigi G, Villa F, Rovera F, Boni L, Carrafiello G, Annoni M, Castano P, Bianchi V, Mangini $M$, Recaldini $C$, Laganà $D$, Bacuzzi A, Dionigi R: Colonic stenting for malignant disease: review of literature. Surg Oncol 2007; 16(suppl 1):S153-S155. 
5 Martinez-Santos C, Lobato RF, Fradejas JM, Pinto I, Ortega-Deballón P, Moreno-Azcoita M: Self-expandable stent before elective surgery vs. emergency surgery for the treatment of malignant colorectal obstructions: comparison of primary anastomosis and morbidity rates. Dis Colon Rectum 2002;45:401-406.

6 Watt AM, Faragher IG, Griffin TT, Rieger NA, Maddern GJ: Self-expanding metallic stents for relieving malignant colorectal obstruction: a systematic review. Ann Surg 2007; 246:24-30.

7 Nagula S, Ishill N, Nash C, Markowitz AJ, Schattner MA, Temple L, Weiser MR, Thaler HT, Zauber A, Gerdes H: Quality of life and symptom control after stent placement or surgical palliation of malignant colorectal obstruction. J Am Coll Surg 2010;210:45-53.

8 Dohmoto M: New method: endoscopic implantation of rectal stent in palliative treatment of malignant stenosis. Endosc Dig 1991; 3:1507-1512.

9 Xinopolous D, Dimitroulopoulos D, Theodosopoulos T, Tsamakidis K, Paraskevas I, Vassilopoulos P, Paraskevas E: Palliation of inoperable malignant colonic obstruction. Comparison and cost effectiveness analysis between stent placement and stoma creation. Ann Gastroenterol 2004;17:294-299.

10 Ptok H, Meyer F, Marusch F, Steinert R, Gastinger I, Lippert H, Meyer L: Palliative stent implantation in the treatment of malignant colorectal obstruction. Surg Endosc 2006;20:909-914.

11 van Hooft JE, Fockens P, Marinelli AW, Timmer R, van Berkel AM, Bossuyt PM, Bemelman WA; Dutch Colorectal Stent Group: Early closure of a multicenter randomized clinical trial of endoscopic stenting versus surgery for stage IV left-sided colorectal cancer. Endoscopy 2008;40:184-191.
12 Zhao XD, Cai BB, Cao RS, Shi RH: Palliative treatment for incurable malignant colorectal obstructions: a meta-analysis. World J Gastroenterol 2013;19:5565-5574.

13 Liang TW, Sun Y, Wei YC, Yang D: Palliative treatment of malignant colorectal obstruction caused by advanced malignancy: a self-expanding metallic stent or surgery? A system review and meta-analysis. Surg Today 2014; 44:22-33.

14 van Hooft JE, van Halsema EE, Vanbiervliet G, Beets-Tan RG, DeWitt JM, Donnellan F, Dumonceau JM, Glynne-Jones RG, Hassan C, Jiménez-Perez J, Meisner S, Muthusamy VR, Parker MC, Regimbeau JM, Sabbagh C, Sagar J, Tanis PJ, Vandervoort J, Webster GJ, Manes G, Barthet MA, Repici A; European Society of Gastrointestinal Endoscopy: Self-expandable metal stents for obstructing colonic and extracolonic cancer: European Society of Gastrointestinal Endoscopy (ESGE) Clinical Guideline. Endoscopy 2014;46:990-1053.

15 Choi JH, Lee YJ, Kim ES, Choi JH, Cho KB, Park KS, Jang BK, Chung WJ, Hwang JS: Covered self-expandable metal stents are more associated with complications in the management of malignant colorectal obstruction. Surg Endosc 2013;27:3220-3227.

16 Ribeiro I, Pinho R, Leite M, Proença L, Silva J, Ponte A, Rodrigues J, Maciel-Barbosa J, Carvalho J: Reevaluation of self-expanding metal stents as a bridge to surgery for acute left-sided malignant colonic obstruction: six years experience. GE Port J Gastroenterol 2016;23: 76-83.

17 Fernandes D, Domingues S, Gonçalves BM, Bastos P, Ferreira A, Rodrigues A, Gonçalves R, Lopes L, Rolanda C: Acute treatment of malignant colorectal occlusion: real life practice. GE Port J Gastroenterol 2016;23:66-75.
18 Fernández-Esparrach G, Bordas JM, Giráldez $\mathrm{MD}$, Ginès A, Pellisé $M$, Sendino $O$, Martínez-Pallí G, Castells A, Llach J: Severe complications limit long-term clinical success of self-expanding metal stents in patients with obstructive colorectal cancer. Am J Gastroenterol 2010;105:1087-1093.

19 Canena JM, Liberato M, Marques I, Rodrigues CI, Lagos AC, Patrocínio SD, Tomé MJ, Cpires EN, Romão C, Coutinho AP, Veiga PM, Neves BC, Deus JR, Além HD, Gonçalves JA: Sustained relief of obstructive symptoms for the remaining life of patients following placement of an expandable metal stent for malignant colorectal obstruction. Rev Esp Enferm Dig 2012;104:418-425.

20 Small A, Coelho-Prabhu N, Baron T: Endoscopic placement of self-expandable metal stents for malignant colonic obstruction: long-term outcomes and complication factors. Gastrointest Endosc 2010;71:560-572.

21 Repici A, Fregonese D, Costamagna G, Dumas R, Kähler G, Meisner S, Giovannini M, Freeman J, Petruziello L, Hervoso C, Comunale S, Faroux R: Ultraflex precision colonic stent placement for palliation of malignant colonic obstruction: a prospective multicenter study. Gastrointest Endosc 2007;66: 920-927.

22 Cennamo V, Fuccio L, Mutri V, Minardi ME, Eusebi LH, Ceroni L, Laterza L, Ansaloni L, Pinna AD, Salfi N, Martoni AA, Bazzoli F: Does stent placement for advanced colon cancer increase the risk of perforation during bevacizumab-based therapy? Clin Gastroenterol Hepatol 2009;7:1174-1176.

23 Abbott S, Eglinton TW, Ma Y, Stevenson C, Robertson GM, Frizelle FA: Predictors of outcome in palliative colonic stent placement for malignant obstruction. Br J Surg 2014;101: 121-126. 